UDC 811:111:656.61 (09) (045)

DOI https://doi.org/10.32838/2710-4656/2021.2-1/30

Nikulina O. L.

National University "Odessa Maritime Academy"

\title{
MARINE ORIGIN OF CONTEMPORARY ENGLISH IDIOMS
}

The origin of contemporary English idioms has its roots in various layers of historical and professional etymological sources of the English language, but since Britain was always a sea country and a marine power depending on the surrounding seas, the large bulk of contemporary idioms descends from marine domain. The sea served always as means of island protection from the invaders and British people depended on the sea as a considerable source of food, like catch of fish. Britain always had a strong elaborate fleet that helped the country not only to defend itself but also to open new lands and make them British colonies, like Canada, Australia, India, etc. No wonder that many everyday English phrases are of nautical/ marine origin. In this research we studied forty-one idiom of nautical origin and decided to systemize them according to their reference to different marine elements, facilities and locations. Not many languages can boast such amount of nautical/marine words and phrases as the English language. The astonishing amount of English idiomatic speech owes to the nautical language of the past. English is extraordinary rich in metaphor and many of the figures of speech that people, speaking English, use every day derive from the language and customs of the sea which fact sometimes we even don't realize. This article is the first attempt of describing and systematizing the idioms and metaphors that over the centuries have been passed on from ship to shore.

The big part of the studied marine idioms is connected with sailing era of British fleet history, with the hostile elements that haunted the seamen at sea, with ships themselves, with their structural parts, and with places originally inherent to human beings dwelling on land. At the time when the first ships appeared and the first voyages started to be organized, the mariners didn't have any maps or navigational aids, they relied mostly on their intuition, professional experience and skills.

In this article we described the researched nautical idioms and distributed them into three groups naming: marine elements, nautical facilities and earth locations correspondingly. The methods used were mostly historical comparative and contemporary comparative. We hope that the suggested work will trigger the interest not only of the seafarers and people related to the marine business, but also to all those interested in the etymology of marine/nautical ESP.

Key words: idiom, colloquialism, marine slang, nautical origin, etymology.

Problem definition. Nowadays when we teach a foreign language, especially English marine ESP, it is necessary to concentrate not only on grammar rules and professional vocabulary, but also on contemporary colloquialisms and idioms, as English is very rich in metaphors, especially of nautical origin, since Britain is and always was a marine power. The analysis and description of the bulk of marine idioms will allow to broaden the horizons of teaching and learning the English language.

Analysis of the latest research and publications. The efforts of foreign linguists in researching the sphere of colloquialisms, idioms, slang so far were concentrated mostly at exploring and analyzing the lexicographic field of this metaphoric bulk of contemporary English language. Such profound publications as "A Dictionary of Nautical Words and Phrases" by Peter D. Jeans, published in 1998, Oxford Dictionaries of Phrasal Words and Oxford
Dictionary of Idioms that appeared in 2020 are the vivid example of the interest to the domain of marine language. As for the local Ukrainian linguistic research tradition, this article is the first attempt to describe and systematize the contemporary idioms of marine origin and the second of the kind after my article "Origin and Etymology of Marine Superstitions", 2020.

The objects of the article. The objects of this article were two-fold: firstly, to investigate, describe and systematize the contemporary English idioms of marine origin according to their importance and impact in the life and work of seafarers; and secondly, to analyze the possible transformation of the original direct meaning of a nautical term into the metaphorical meaning of an idiom and comparing the two, i.e. to trace how farfetched the idiomatic meaning is and whether it is possible to decipher the original marine direct meaning. 
Main part. All people who use English as their mother tongue or those who speak English at work are seldom aware how many dictionaries' entries we owe to marine or nautical English. Of course it can be easily explained by the historical impact of the Royal Navy and British merchant fleet on the English culture, development of the powerful empire, whose language is spoken all over the world and is considered an international language number one. But our interest to the subject was provoked by the fact that few people realize what stands behind such expressions as "take it easy", "high and dry", "ship-shape", "dire straits", etc. although the close look definitely suggests something connected with the sea and seafarers.

It is always interesting for a researcher to find etymological roots of the expressions that we use nowadays. In our previous works we researched and described the nautical origin of contemporary English colloquialisms and superstitions connected with the sea and mariners. This article we decided to dedicate to the research of the marine origin of contemporary English idioms, and of course we'll start here with the definition of "idiom" and what is the term's main difference from such close linguistic terms as "colloquialism", "slang", "phrasal verbs", "jargon etc.". While "colloquial" means a phrase or a word which is used in informal conversation, but not in formal speech ; "slang" is interpreted by many dictionaries as very informal, brand new, not very polite words used among particular groups of people; "phrasal verbs" as the term speaks by itself is a verb followed by a preposition (postposition word would be more correct) which changes the meaning of the whole phrase, sometimes drastically; "jargon" is specific vocabulary of different professions (seafarers, doctors, lawyers); "idiom" is something really different.

Since the target of the given article is "idioms" it is but necessary to define what an idiom means. Addressing the profound and honored dictionaries we found the following definitions: "a group of words whose meaning is different from the meaning of the individual words" [1, p. 140], "a phrase which means something different from the meanings of the separate words from which it is formed" [2, p. 655], "an expression whose meaning is not predictable from the usual grammatical rules of a language or from the usual meanings of its constituent elements" [3, p. 668], "peculiar mode of expression" [5, p. 226]. We think that although the sources are very reliable, the definitions of an idiom sound a bit ambiguous and for an inquisitive person, who relies on his logic, may mean nothing substantial.
We take the liberty here to suggest our own definition to an "idiom". An idiom is an expression that simultaneously realizes two meanings: the direct one and the metaphorical one, but the second metaphorical meaning is contemporarily predominant and usually people immediately think about the metaphorical and not direct meaning when they hear an idiom. For example, we may presume that somebody may bring a bag someplace with a cat inside and then let the cat go, but why would somebody carry cats in bags nowadays? It seems ridiculous. Automatically in this case people would think of the idiomatic meaning of the phrase - "to reveal a secret".

By the way, since the topic of this article is contemporary English idioms of marine origin, we can reveal a secret of the idiom "to let the cat out of the bag" from the nautical point of view. The expression "to let the cat out of the bag" is a widely used colloquial one and means "to tell a secret carelessly or by mistake". This metaphor also takes its roots in nautical slang. "To let the cat out of the bag" was to put an unpleasant state of affairs into motion'. The point is that the cat$o$ '-nine-tails' (nine-lashed whip used for punishing seamen) was traditionally kept in a bag made of baize, and when this "cat" was taken out of the sack it definitely meant the punishment was to arrive. The seamen had a specific ironic humor, so they compared the punishment tool with a purring domestic cat. Luckily, this colloquial expression of marine origin is not connected with punishment today.

The aim of this article is to systematize contemporary English idioms of marine origin. This is the first attempt of philological scientific research like this in Ukraine and the reason of such research is to attract attention to such an interesting field of contemporary philology as idioms and also to draw the attention to the fact that many of English words originate in nautical/marine language. In the course of analyzing the English idioms of marine origin we figured out three functionally different groups of naming things, objects and people which formed the basic semantic frame of an idiom. The mentioned three groups are:

1. Names of elements where seafarers worked and were dependent on, e.g. sea, ocean, weather, wind, storm, strait, waters, etc.

2. Names of facilities that seamen performed their job with, e.g. ship, vessel, boat, sail, mast, etc.

3. Names of locations originally inherent to human beings' dwelling, e.g. land, shore, coast, etc.

The first group of names contains such integral notions that seamen cannot imagine their life without, namely, it is the habitat where they work, i.e. sea, water, 
ocean, river, etc. so the origin of these idioms dates back to such spheres. Very often when English speaking people use such idioms they never think of the origin of the phrases as of marine ones, for example, let's take the idiom "between the devil and the deep blue sea". The phrase "between the devil and the deep blue sea" in metaphorical sense is used in contemporary English in the meaning of "facing two choices, both of which are unpleasant" [6, p. 348]. The marine origin of the expression is easily detectable. The devil on board ship was the outermost seam on the deck, it was called so because it was practically impossible to hammer the caulking in to make the seam watertight. It is also the name of garboard seam between the keel and the first plant which was also difficult to caulk. For the sailor all that lay between disaster and his present position was the thickness of the planking that stood between the devil on the deck and the sea around the ship. "the "deep blue sea" was the inevitable dire result if the sailor neglected to carry out the necessary and always difficult task of keeping the devils in good order" $[1$, p. 36]. That's how the metaphor appeared, to be placed between two alternatives, each of which is equally precarious or hazardous.

One more interesting idiom is "there are plenty more fish in the sea" which means "there are many other people or things that are as good as the one somebody has failed to get" [4, p. 129]. The synonym of the word "sea" in the meaning of the big basin of salty water covering the Earth surface is "the ocean", the word which also gave birth to many contemporary English idioms. "An ocean of something" means a large amount of something and often is not connected with an ocean at all, like in the phrase "an ocean of food" which means just plenty of food. Another frequently used idiom is " $\boldsymbol{a}$ drop in the ocean" which exists in many languages and means a very small amount in comparison to the much bigger amount which is needed, i.e. practically nothing.

Sea and ocean associates with salty waters, no doubt the word "water" enters many English idioms that have the marine roots. The idiom "in deep waters" is easily read as something not very safe and trouble making. The idiom means to be in trouble or difficulty. Very close to the mentioned expression is "to be/get into murky/uncharted waters". The idiom is used to describe a difficult or dangerous situation that you do not know anything about. Murky water is dark or dirty water and you can never know what is under it. If somebody is in uncharted waters, they are in an area of sea or ocean that is not known or recorded on a chart [4].
Nowadays with all the modern gadgets and navigational computerized systems the good weather may not be as vitally important as it used to be in the era of sailing ships, when the life of people and the vessel directly depended on good wind and weather. That is why we can find the word "weather" in contemporary English idioms. A wellknown idiom/colloquialism "to be under the weather" can be easily decoded as to be under the influence of bad weather, to feel blue, to feel unwell. It is also a colloquialism for being inebriated, drunk. But the phrase is definitely connected with the sea and this is transparent. Usually when the sea is rough and it's storming even not heavily, landsmen may be inclined to seasickness, nausea, which is the visible symptom of being under the influence of the weather. The traditional belief is that seamen do not succumb to seasickness, although "Lord Nelson himself freely admitted to being seasick for a day or two whenever he went to sea" [6, p.175].

The word "wind" is also very popular in many English idioms and definitely it comes from marine language of the sailing ships era. One of the vivid example may be "to take the wind out of somebody's sails", the idiom means to make somebody suddenly less confident or angry, especially when people do not expect bad news. This metaphor meant that all of a sudden the wind at sea changed drastically or just died out and the ship could not proceed because the sails dropped dead. Another example that should be mentioned here is the idiom "sail close to the wind" which means to behave in a way that is almost illegal or socially unacceptable.

Another marine word that enters the first group is "storm". Definitely ships even nowadays prefer to escape the storms at sea because their damage is usually unpredictable. That's why the idioms that contain the word "storm" describe something very unpleasant, unpredictable, extreme or of emergency kind. The idiom "the calm/lull before the storm" is pretty transparent and means a period of unnatural calm before an attack, violent activity, and not only at sea, but in business situation or whatever. It is interesting to trace here that the word "storm" originates from ME "stir" (stiren) which meant "o disturb, to scatter, destroy"; now literally "storm" means "that which lays low" [4, p. 495]. Now the word "storm" is first and foremost associated with very bad weather mostly at sea, it entered many expressions and gave birth to the idioms which are not necessarily connected with marine/ nautical origin. For example, when people use the idiom "a storm in a teacup" they mean a small or unimportant problem which is treated 
much more seriously than it really should be. But it's only fair to say that one can find much more idioms in the contemporary English where the word "storm" would rather mean a difficult, deadlock situation, e.g., "ride out/weather the storm (of sth)" which means manage to survive a difficult period or situation.

One more typically nautical term is "strait" which means a narrow natural water passage between two pieces of land, like a Strait of Dover between the Great Britain and the continent. Historically on French charts and maps the same water space is called Pas de Calais. The point is that the broader part of the water distance between England and France is called the English Channel in English and La Manche in French. The word "strait" gave birth to a well-known idiom "dire straits" that means in contemporary English "to be in a very difficult situation and may go bankrupt" [1, p. 410]; "to be in a serious difficult position, causing great fear for the future" [2, p. 359]. Originally "dire straits" meant difficult, troublesome passage of water for the ship to pass, so when in the late 80 -ies a rock group appeared with the name "Dire Straits" the contemporary young people may have sooner thought about the obstacles that the band had to overcome in the tough competition with the other rock bands. The group was pretty successful and they did overcome the competition of the time, but the young fans hardly ever thought of a marine origin of the name of their favourite band.

The second group of idioms that we have analyzed and are about to describe here is "Names of facilities that seamen performed their job with, e.g. ship, vessel, boat, sail, mast, etc.". All the necessary equipment on board ship is designed to provide the sailing, propulsion, navigation controls, cargo handling operations, personal safety which always was and is vital for the seamen to ascertain and control that the ship performs its main functions. Here in this paper we research contemporary English idioms of the marine origin and we realize that most of the idioms, irrespectively of their origin, are historical products of the live evolution of the language. Definitely some time has to pass before a word or phrase enters the language, that's why most of the idioms and colloquial expressions that exist in the English language now date back to some historical times. The same way the idioms and colloquials of nautical/maritime origin have roots not in the contemporary but historic language of shipping and maritime business.

One of the most frequently used marine term in colloquials and idioms is "ship" or sometimes "boat" in a pretty similar, synonymous meaning. Definitely for a seaman who used to spend months, even years on board ship, the latter became his second home, hence logically the idioms with "ship" as a component should have contained the positive connotation, like the "home" for all of us does. Practically the most of marine idioms contain the word "ship" as a positive ingredient but some of them do not. Let's look at the expression "when your ship/boat comes in", definitely it is of a positive connotation, because when a seaman was waiting for a ship that could give him engagement, coming into the port and hiring him, that was a good sign. That is why nowadays the idiom means "when you are suddenly successful or have a lot of money" [4, p. 349].

It goes without saying that everything on board ship should be kept in good order and that is why one of the first and foremost rule with the seafarers. Otherwise the terrible thing may happen during a disaster. Everything on board should be kept an eye to and everything should be "tight and tidy". Hence the expression of marine origin which is clearly read now as "keep everything in good order" is "run a tight ship" which means "run a business, organization, etc. in a strict and efficient way" [4, p. 410].

The next idiom that we are presenting here is very close to the previous in a sense that everything on the ship should be properly done according to the orders and standard requirements, ship-shape (by the way, this idiom also comes from maritime slang). The phrase is "shape up or ship out" which means directly on board ship "either use, obey and correspond to rules or you will be made redundant and dismissed from the ship". The idiom appeared in the contemporary English with a rather transparent meaning "if you do not work hard and do not try to improve you will have to leave the job or position" [5, p. 347]. The idiom is more frequent in American English.

As was mentioned above the seme "ship" joined the bulk of English idioms not only with positive connotation, but with if not negative, then definitely not one on the pleasant side. The first example of such an idiom is "to jump the ship" / "to jump ship" which originally was a purely nautical term and meant "to leave the ship on which you are serving without permission" [4, p. 198], which of course was illegal and punishable. Nowadays the idiom means practically the same but is not connected with a ship, i.e. "to leave an organization that you belong to suddenly and unexpectedly". That careless action is usually not approved of and appraised by the administration. In the old days such sailors-traitors were not in honor and sometimes it was difficult for them to find job on a different ship. The same situation 
is now, if somebody "jumps ship" from a prestigious company, he will be entered into a blacklist and it will be problematic for the person to find a decent job, at least in the same sphere.

Another idiom containing the seme "ship" contains humorous and disapproving connotation: "desert/ leave a sinking ship". Usually animals are more sensitive to the changing weather conditions and they feel much sooner than people when their habitat may be exposed to danger. There is no secret that rats always accompanied sailing ships because there was plenty of food in the holds and the sanitary rules were practically neglected. The rats as wild animals were the first to leave a ship before the forthcoming danger, like sinking, shipwreck, fire, etc. Rats were always an object of despise with people mostly because they infected people with contaminable deadly diseases, that's why the word "rat" in colloquial contemporary English is associated with something disgusting, squeamish i.e. "rat" - an unpleasant person, especially one who is not loyal or who tricks somebody [1, p. 1203], "smell a rat" - think or suspect that something is wrong or somebody is trying to deceive you" [4, p. 365], "drowned rat"-very wet, "ratrace"intense competition for success in jobs, business, etc. In connection to the marine history usually it's a naval code, that in case of any emergency situation that may cause peoples' death and ship's sinking it is the captain of the ship who is the last to leave. The idiom now is used to talk about 'people who leave an organization, a company that is having difficulties without caring about the people who are left' [4, p. 359].

One more idiom that we can reveal the secret of here is "spoil the ship for a ha'porth/ha'pennyworth of tar". From the first sight it looks like a pretty strange undecipherable idiom having no connection to ships or marine business. It really has no connection to nautical origin, but we shall try to decipher it. First we have to figure out what is "tar". Tar is sick black sticky liquid that becomes hard when cold. An inquisitive person would ask a question: "Where comes here a ship and how can one spoil it with tar?" The decoding of this idiom lies in the history of the English language transformations. "Ship" in this idiom was originally "sheep" and "ha'porth or ha'penny-worth" referred to a very small amount of money. The basic meaning of the idiom was "to allow a sheep to die because you won't buy a very small amount of tar to cure her cuts" [4, p. 374]. Nowadays nobody thinks about ships or sheep while using this idiom because it means "to spoil something good because you did not spend any or enough money or time for even small amount of it".
The word "boat" may mean "a vehicle (smaller that a ship) that travels on water" [1, p. 152], or it may be just a synonym to the word "ship". During our research we payed attention that although 'boat' is not as popular a component of English idioms as "ship", still the word has entered many colloquial expressions. The expression that exists in many European languages is "to be in the same boat". Its meaning and its nautical origin is transparent: when people share the same boat with only water around and sometimes no means to escape, they are absolutely equal in front of the danger, be they rich or poor, black or white. This contemporary idiom means "to be in the same difficult position or situation as somebody else" [4, p. 35].

In the beginning of this article we mentioned the important fact about idioms: they realize simultaneously two of the meanings - direct and metaphorical. When we speak about the situation when we missed the last bus or train, it's very unpleasant if not irritating because we have to wait for the one tomorrow. Some languages, like Russian and Ukrainian have the expression "your train has gone" and it means "it's too late to do something to amend things". In English there is an expression which is practically synonymous: "to miss the boat" which means "to lose the opportunity to do or get something because you do not act quickly enough" [4, p. 247].

If you imagine a situation that you sit in a tiny boat and somebody or the storm is rocking it so that she can capsize and you may fall overboard, - such situation is dangerous. No wonder the expression "to rock the boat" is easily decoded by English speaking people and mean 'to do something that might upset, cause problems or change the balance of a situation [4, p. 329]. Some other interesting idioms that contain the word 'boat' are: “to float somebody's boat" - be, do what somebody likes "whatever floats your boat" means whatever you like; "push the boat out" spend a lot of money on food, drinks when celebrating a special occasion [4, p. 310].

Another interesting idiom worth attention here is "burn your bridges/boats". Again the meaning of the idiom is clear: if one burns the bridges or boats behind him it will be impossible for him to retreat. Nowadays in English the expression means "to do something that makes it impossible for you to return to a previous situation"; "to destroy all means of going back, so that one must go forward" [2, p. 157].

The phrase "to be on board" means to be in/on a ship, an aircraft, train, bus, which is a plain, direct meaning. The expression "on board" also forms an idiom "take something on board" meaning 'to 
accept an idea or a suggestion; to recognize a problem [4, p. 35].

Since the history of nautical/marine language dates back to mainly the sailing era of seamanship, it is but obvious that one of the common and frequent word in pro-marine idioms will be "sail". If we look into the etymological dictionaries of the English language we'll find out that "sail" meant "that which endures or resists the wind" [5, p. 434]. Let's find out whether the original meaning of the word is traced in the contemporary idioms. The first example of such idiom will be "trim your sails", which originally meant "to arrange the sails of your boat to suit the wind, so that the boat moves faster" [1, p. 1581]. In nowadays English the idiom means "to cut expenses, to economize" [ 3, p. 1426].

Next interesting idiomatic expression to dwell about here is "to take the wind out of somebodies'sails". It's but natural that if there was no wind during the days of sailing vessels, sails were useless because the wind was the only power pushing the ship to move along the water. It is clear that if the wind is out of somebody's sails it's too bad, the dead alley situation. Nowadays the idiom means 'to make somebody suddenly less confident or angry, especially when you do or say something that they do not expect [5, p. 449].

Another interesting expression containing the seme "sail" is "it's all plain sailing" which has undergone the diametrically opposite transformation in the language just because of one-word mistake. The word "plain" in contemporary English means "easy, clear, honest, direct, simple". If we take this meaning into consideration the expression "plain sailing" would mean easy, "simple sailing" and as an idiom today it means "simple and free from trouble" $[1$, p. 1106], "anything straightforward and easy to do" [6, p. 139]. Historically the phrase referred to "plane sailing" which was "the art of determining a vessel's position on the assumption that the earth is flat and the ship is therefore sailing on a plane surface [6, p. 139]. So "plane" was transferred into "plain" because it was easier to plot the ship's course and to calculate the route on a plane chart.

"Mast" as a constructive part of the ship is very important today, but just imagine how important it was in the days of sailing fleet, because all the sails were fixed to masts and the ships were named after the number of masts on board. No wonder "mast" is a popular entry to marine idioms. Here we'll explore the idiom "nail your colors to the mast". First of all, we need to explain that the word "color" in marine English means "a flag" of a country where the ship is registered. Now the idiom means "to show clearly which side you support" [4, p. 255], but historically it used to mean that a ship showed its intention to continue fighting in battle and not surrender by nailing its flag to the mast.

Another integral constructional part of the ship's construction is "deck", so definitely it entered the bulk of marine idioms. "Deck" on board ship is like floor in a house, so sometimes it is easy to decipher the meaning of the marine idioms, but sometimes not. For example, let's concider the idiom "clear the deck". Before doing something on deck, like cargo handling, mooring, bunkering the seamen have to clear the deck space from anything that may get in the way, hence the meaning of the idiom is clear - "to prepare for an activity, event by removing anything that is not essential" $[1, p .261]$.

One more interesting idiom with the word 'deck' is "all hands on deck". In colloquial English the expression means that everyone should help or must help in case of emergency. The marine origin of this idiom may be traced not only from the term "deck" but also from the word "hand" which in marine language means "a sailor". This was a command given on board ship in case of unpredictable or complicated situation when all seamen free from watch or emergency work had to arrive on deck to their muster station and had to be ready to perform any commands from their seniors.

The word "deck" is often used in metaphorical sense as "any flat surface" like floor in the house, that's why in the expressions "hit the deck" the word means just "ground"; fall to the ground suddenly. In American version the idiom may also mean "to get out of bed".

The third group of idioms contains names of locations originally inherent to human beings' dwelling, e.g. land, shore, beach, etc. needless to say that the seafarers of the older times were spending much more time at sea, on board their ships than ashore, the latter being the natural habitat of the homo sapience. Some seamen never had families on land, still they came ashore from time to time, landed. It's but natural that many English idioms contain the elements connected with land, not with sea.

The first word that gave birth to contemporary English idioms and which we'll examine here is "coast". And the first expression that we'll describe here will be "the coast is clear". Nowadays the expression means that there is no apparent likelihood of interference, there is no enemy in sight; "there is no one around to see or stop what you are doing" [4, p. 65]; "nothing is present that would impede or endanger one's progress" [3, p. 260]. the idiom stems from "the clear coast" that dates 
back to the days of smuggling. If the coast was clear, it meant that there was no coast guard or any other control services that would check for or interfere with smugglers' activities.

Another idiom that contains the word "coast" is "to coast along" which in contemporary English means "to put very little effort into something" (used in a disapproving sense) [1, p. 272]. Historically this phrase is definitely connected with marine usage. "To coast" is to sail along the line of the coast; a coaster is a small ship like a pilot boat that sails between the harbors or adjacent coasts. Such vessels encountered few serious obstacles to a safe passage because they were always within the sight of land; they could fix their position with great accuracy and they could always find shelter in the nearby haven in case of bad weather. So it's clear that colloquial meaning of "to coast along" is to carry out a task with minimum effort, without unnecessary fuss or bother [6, p. 28].

Next idiom to undergo our description will be "no-man's land". The expression originated in marine slang and meant the space amidships of a vessel, between the after part of the forecastle and the foremast. In this place usually were kept the ropes and everything needed to work at the forecastle. The name derives from being neither on the starboard nor the port side. Later this term was applied to the area of land between hostile lines of entrenchments or to any space contested by both sides of the combatants and belonging to none. This idiom is used not only as the army slang but also as the contemporary colloquial English meaning "wildness, a place to be avoided as dangerous" [6, p. 91].

One more idiom worthwhile mentioning here is "to hit/reach rock bottom" or "be at rock bottom". Definitely its clear connection with marine language is seen with a naked eye. If a ship hits rock bottom it means that she has run aground which is a very unpleasant delay because sometimes the vessel would need the extra external assistance to tug her in the waters again. In contemporary English the idiom means "reach or be at the lowest point or level that is possible" [4, p. 329]. Another synonymous expression to the idiom above is "high and dry" which is often used in contemporary colloquial English in the meaning of "in a helpless situation, in a difficult situation without help or money" in British English and "deserted, stranded" in American English. As a nautical term it was said of a ship that has run aground so that the tide gradually exposed the keel.

An interesting metaphor which also contains the marine objects that we can find on land has entered the contemporary colloquial English language - "not the only pebble on the beach". The meaning is informal and disapproving "not the only person who is important or should be considered" [4, p. 286]. The word "beach" also is a constituent of a colloquialism "beachcomber" which may mean either "a person who lives by gathering salable articles of jetsam, refuse from beaches" or "a vagrant who lives on the seashore" [3, p. 119].

Conclusions and suggestions. The object of the article is the bulk of idioms in contemporary colloquial English which are of nautical/marine origin. The result of the research is as such - three functional groups were singled out:

1. Idioms which name the elements that seafarers encounter with, such as sea, ocean, weather, storm, etc.

2. Idioms which name the facilities on board ship that the seamen work with, e.g. ship, sail, deck, mast, etc.

3. Idioms which name the locations originally inherent to human beings' dwellings, e.g. coast, shore, land, beach, etc.

In future we consider the necessity of further research and description of contemporary colloquial English phrases - colloquialisms, idioms, phrasal verbs connected with sea and seafarers. We hope this article will be of use and interest not only to teachers of marine ESP and seafarers, but also to those who learn English in its evolution as a living organism.

\section{References:}

1. Hornby A. S. Oxford Advanced Learner's Dictionary of Current English. Oxford university Press, 2005. 1715 p.

2. Dictionary of English Language and Culture. London Group UK, 1992. 1528 p.

3. Random House Webster's College Dictionary. USA, 1995, 1555 p.

4. Oxford Idioms. Dictionary for learners of English. Oxford University Press, 2020. 469 p.

5. Walter W. Skeat, Concise Dictionary of English Etymology. Wordsworth Reference, 2007. 643 p.

6. Jeans P. D. An Ocean of Words. A Dictionary of Nautical Words and Phrases. Toronto, Ontario : Carol Publishing Group, 1998. 180 p.

7. Opie I., Tatem M. Dictionary of Superstitions. Oxford, New York : Oxford University Press, 1996.

8. Beavis B., McGloskey R.G. Salty Dog Talk. The Nautical Origin of Everyday Expressions. London : Sheridan House ; New York : Granada, 1983. 96 p.

9. Eric Partridge. A Dictionary of Historical Slang. Penguin Books, UK, 1977. 1065 p.

10. Nikulina O. L. Origin and Etymology of Marine Superstitions. Нова філологія : збірник наукових праць. Запоріжжя : Запорізький національний університет, 2020. № 80 б. Т. ІІ. С. 83-88. 


\section{НікУЛіна О. Л. МОРСЬКЕ ПОХОДЖЕННЯ СУЧАСНИХ МОРСЬКИХ ІДІОМ}

Походження сучасних морських ідіом сягає корінням різноманітних шарів історичних та професіональних етимологічних джерел англійської мови, але оскільки Велика Британія була завжди приморською країною та морською державою, що залежала від навколишніх морів, велика кількість сучасних ідіом походять із морської англійської мови. Море завжди було осередком захисту країни від загарбників, англійці ж залежали від моря як від споживчого ресурсу їжі, зокрема й риболовлі. Велика Британія завжди мала сильний розвинений флот, щь допомагав країні не тільки захищати себе, але і відкривати нові землі та перетворювати їх на британські колонії, як-от Канада, Австралія, Індія тощо. Тому не дивно, щзо багато сучасних розмовних англійських висловлень мають морське походження. У иъьому дослідженні ми проаналізували сорок одну ідіому морського походження, систематизували їх згідно з їхнім зв'язком з назвами різних морських стихій, суднових приладів та місчевостей. Не багато мов можуть похвалятися таким відсотком морських слів та висловів у своєму тезаурусі, як англійська мова. Багатство англійської ідіоматичної мови завдячує морській мові минулого часу. Англійська мова дуже багата на метафори і фігури мови, які вживають $і$ зараз, і люди, щэо спілкуються сьогодні, не асоиіюють їх із проморським походженням. Ця стаття є першою спробою описати та систематизувати ідіоми та метафори, щчо сторіччями передавались із судна на берег.

Значна частина оброблених морських ідіом пов'язані історично з вітрильним флотом Великої Британії, із брутальними стихіями, щео переслідували моряків у плаванні, із самими суднами та їхніми структурними частинами, а також із місиями, де первісно прожсивали люди, тобто із землею. У час, коли перші судна з'явились, розпочалися мандрівки морем, моряки не мали сучасних морських мап та навігаційних пристроїв, тому вони сподівалися на свою інтуїцію, професіональний досвід та навички.

У статті ми описали досліджені морські ідіоми, розподілили їх на такі групи, як назви морських стихій, назви суднових пристроїв та назви місиезнаходжень. Методи дослідження - історично-порівняльний та сучасно-порівняльний. Ми сподіваємось, що ия робота спровокує інтерес до теми не тільки моряків та людей морського бізнесу, а також усіх, хто ичікавиться етимологією морської професійної англійської мови.

Ключові слова: ідіома, колоквіалізм, морський жаргон, морське походження, етимологія. 